\title{
Rethinking About Megalithic Term In Indonesian Culture
}

\author{
Lutfi Yondri \\ \{yondrilutfi@gmail.com\} \\ Balai Arkeologi Jawa Barat
}

\begin{abstract}
Etymologically, megalithic means mega: large; and litik: stone, in the context of culture is defined as a big stone culture. In the field of cultural knowledge and the study of the past, megalithic terms such as megalithic culture, megalithic era, megalithic traditions, as well as megalithic cultural traditions are often found. This article tries to describe the use of the term megalithic, because from the results of archeological research and cultural development in Indonesia, it seems that many megalithic notions are incompatible. Large as a size is no longer used as a benchmark, even stones with a small size, its size is less than $50 \mathrm{~cm}$ and cultural products made from wood that are used for ritual worship of spirits are also categorized as megalithic, and even more interesting is the mention of the megalithic period. To unravel these problems, a descriptive review was carried out on the ingredients, the types of ingredients, and the size of the cultural products used. Based on the results of the study it can be concluded, the term megalithic cannot be applied in general. Megalithic mention can only be done casually. The term that is more appropriate to use is a term related to its function as a medium of ancestor worship, and then referred to ancestor worship culture not megalithic culture.
\end{abstract}

Keywords: culture, megalithic, material, size, and function

\section{Introduction}

Some problems about megalithic culture in the world also occur. Some experts among them try to discuss about differences measuring in the size of material [1], megalithic culture and landscape [2], orientation of megalithic structure (Prendergast, Frank, 2016), megalithic traditions in society [3], megalithic culture related to the funeral ritual [4], megalithic values in classical culture in Indonesia [5], and also related to the meaning of the megalithic remain [6].

Like in the other place in the world, culture in Indonesia has a dynamic, it was growth and developed from prehistoric era until now. The dynamic of Indonesian cultural during the prehistoric era had been exhibited on several steps of the development. The prehistoric remains that had been found can be classified into three categories such as hunter-gather, agriculture, and the era of skill in metallurgy. Especially in agricultural era, it has one of cultural product called as the megalithic culture, which was symbolized by huge stones [7]. At last, as a tradition, it had been changed and visualized in several kinds of source or material 
for building it monument. Based on archaeological findings, some of scientist concluded the megalithic tradition is one of the main traditions ever existed. It was called the main tradition because that culture has spread almost in every area, and able to expand within a short time since its first appearance when agriculture was first known. related to this, in one culture various criteria are very influential in determining the form of a civilization [8].

Some problems about megalithic culture in the world also occur. Some experts try to discuss it by reviewing it at several archeological sites discovered later. There are so many problems related to megalithic culture, especially in the Asian region Loofs in his book Element of the Megalithic Complex in South East Asia (1967) says "The megalithic cultural complex, la plus grande enigma de la prehistoire as it has recently termed, has never ceased to occupy a prominent place in popular imagination as well as in scholarly debate. In the last few years, however, this debate not only seems to have gained in strength but also to have brought about the recognition of the importance of this question for our understanding oh the history of civilization [9]. Especially in Indonesia culture, the first problem about megalithic occur in chronology and its arrival to Indonesia, according to Heine Geldern, he grouped it in two waves. The first wave, known as the Old Megalithic Culture, presumably extended during the Neolithic Period, between 2500-1500 BC, whereas the second wave called the New Megalithic culture, was presumed to emerge about the early first millennium $\mathrm{BC}$. The megalithic culture had come to Indonesian area by the Austronesians people who brought the square pickaxe cultures [10].

From Heine Geldern's point of view it can be assumed that the arrival of megalithic culture in Indonesia was caused by the cultural migration or human migration to Indonesia in the past. This migration is that some experts concluded out from Asia mainland through Taiwan, and then arrived in Indonesia, but it didn't occur on Geldern chronology. Based on the views expressed by [11],[12], [13] concluded the Austronesian up and growing in Indonesia through five stages. Phase I is the stage of the migration of farmers from southern China reached Taiwan (5000 years BC), Phase II, migration from Taiwan to the Philippines (2500 BC), Phase III, the migration from the Philippines to the south and southeast (towards 2000 BC), Phase IV, migration from North Maluku to the south and east (2000 BC), and the phase V migration of northern Papua westward and eastward [13]. According to Munandar (2012) when the migration was rarely done, and Austronesia people had settled and steady in some areas of Southeast Asia, there is an opportunity to further develop the culture better. Based on the artifacts, it can be interpreted to mean that between $5 \mathrm{BC}$ untill $2 \mathrm{AD}$, there is a form of culture that is based on intelligence that was later known as the Dong Son culture [14]; [15] .

Related with the interpretation about stages and when the Austronesian settled in Indonesia, untill now no artifact also archeological site had chronology like Geldern's says. Numbers of archeological site with megalithic remain such as upright stone (Menhir), dolmen, stone terraces, etc. are coming from later period. According to Sutaba (1991) with his statement as megalithic culture in Indonesia had developed around late prehistoric era or paleometalic period [16], but it doesn't support by any kind of data and absolut dating or chronology. Prasetyo (2013) tried to count several megalithic sites in Indonesia, and found that all of site are coming from long time after Geldern's chronology, such as: Hiligeo (Nias): cal. 15-10 AD, Tundrumbaho (Nias): cal. 15-17 AD, Guguk Nuang (West Sumatra): cal. 1013 AD, Bukit Batu Larung (Jambi): cal. 10-13 AD, Bukit Arat (Jambi): cal. 7-11 AD, Dusun Tinggi (Jambi) cal. 4-7 AD, Renah Kemumu (Jambi): cal. 11-13 AD, Banua Keling 1, 2, 3, 4 (South Sumatra): cal. 13-17; 11-13; 7-10; 3-6 AD, Tebat Gunung (South Sumatra): cal. 11-14 AD, Pajar Bulan 1 dan 2 (South Sumatra): cal. 10-13 and 7-12 AD, Pasir Angin 1 dan 2 (West 
Java): cal. 9-10 and 10-11 AD, Kidangan (East Java): cal. 15-17 AD, Krajan Bayeman (East Java): cal. 6-11 AD, Pedaringan (East Java): cal. 10-14 AD, Dawuhan (East Java): cal. 7-9 AD, Doplang (East Java): cal. 13-15 AD, Woloan 1, 2, and 3 (North Sulawesi): cal. 4-7; 8-10; 7-9 AD, Tatelu 1 and 2 (North Sulawesi): cal. 4 SM BC - Early Century and 11-14 AD [17].

New chronology coming from Gunung Padang site (West Java) from carbon dating analysis, that site was built around 117 until 45 BC [18]. All of site chronology the author thinks can be used as the adding data in interpretation about when this culture was arrived and developed in Indonesia. With the extent of development, cultural values of it had emerged among various contexts and time. The emergence of cultural values in multi contexts certainly had the implication of the material that was used. With the limit of physical environment as medium of material provider, visualization of the cultural values would not be relied upon one single kind of material but also using other materials. In this case, material for visualization of cultural values was no longer held its definition "mega" meaning big or huge, and "lithos" meaning stone [19]. Smaller sized stones and other materials such as wood, also took an important part in the cultural appearance of object. Therefore, in this study, the author does not hold on the standard definition of the word megalithic but tries to study it based on the material or element that were used in visualizing.

The meaning of megalithic in reality was not always connected with huge stones. The deeper meaning of megalithic cultures has been suggested by van der Hoop (1938) and Wagner (1962) Van der Hoop said that megalithic objects are not always made of huge stones, but sometimes using smaller stones. If the people or community in a certain area could not find the right stones to make a building, then they used wood to substitute them [20]. The other objects like wooden statues, which are found in Indonesia, are rarely above 200 years old. Although having various forms, these statues illustrated magical and supernatural elements. For example, the find from Luang Semata Island, between Timor and Tanimbar illustrated an ancestor figure [20].

F. A. Wagner (1962) referred to megalithic culture from its ceremonial activitiy aspects. In his book which is titled Indonesia, the Art of an Island Group, he said that the megalith which is up to now understood as huge stones, in some places using smaller stones and other materials like wood, should also be classified as megalith, if those objects used for a certain sacred objective, like the worshiping of an ancestors spirit [21]. In Wagner suggestion a contradictive statement was occur, smaller stone is not a big stone although it has a function in ritual. The wood also. It's not a stone and different material with stone.

From the understanding mentioned by Loofs, van der Hoop and Wagner, megalithic term become difficult to understand because it contain the contradictory. Contradictive in material, and the size of material that used. Based on those mentioned could be summarized the megalithic term till has a problem, is it term related with material or function? The cultural value with various materials can be assume as a represented a concrete form a symbolic system, it can change and develop related with its environment.

\section{Research Methods}

The object of this research is the material cultural which is classified as megalithic in Indonesian culture, both included in the group of relics from prehistoric periodization and which then continues as a tradition in some traditional societies in Indonesia. The cultural remain is analyzed using descriptive analysis which is then associated with its function both related to sacred (material used for the cult ancestral spirit and burial), and profane activities. 


\section{Result And Discussion}

In such culture, we often found cultural concept with similar root in several areas. Variety would be happened in shape, form or element, which was chosen to be used. On this matter one cultural value could change structurally and how was efficiency of environment resources and how did adaptive pattern form their material culture. Theoretically, men need to survive in nature, which according to Sumarwoto (1994), consisted of: (1) basic need of physical survival; (2) basic need of human survival; and (3) basic need to choose. From the three different basic needs mentioned above, which was connected directly to cultural issues is the basic need to choose. To fulfill the basic need, the ability to choose is not only to fulfill physical survival, but also to express its culture [22]. Therefore, basic needs to factor of choose exerted on emerging material culture form one culture. Then, all of that are making the community and culture not withstanding in some characteristic culture. From that matter, three factors influencing each other could be desired [19]; [15].

Likewise, ancestral worship tradition, basically remains of culture accumulated on one site was part of a residential region in a holistic way in the past. Besides sacred site, there were also other variables in that region such as dimension of thought, landscape, dwelling place, wet/dry rice field, water, and material resources and so on. From ecological view, megalithic sites were also one of part of settlement in that dimension of society were able to visualize their cultural values with various symbolic systems which have mutual agreement according to resources provided on their settlement. Therefore, visualized forms of the same root of cultural values with different will emerge different visualization. The difference would happen on the basic of material that as used, because an environment can limit in usual resources to make monument with similar cultural values in another area. In course of the long history of development, the spread of ancestral worship tradition also has the undergone cultural dynamics. The dynamics belongs to a system of thought which occurs in various contexts, values of concepts those exist in cultural tradition undergoing various changing on their visualization. On certain areas ancestral worship tradition community used wood and smaller stones. The cultural values can be change in material, also in structure. It is very related with the utilization of environmental resources and how the cultural adaptation patterns. Through a semiotic approach in the study of megalithic culture in Indonesia Sudarmadi (1999) concluded that Indonesian megaliths are very large in type, date and distribution, in most parts of Indonesia, they are still associated with myths, and ancestor worship, and some of these ideas embedded in aspects of Indonesian culture.

Research on megaliths in Indonesia so far seems to have not broken down in more detail from the remains that are categorized as megalithic culture, most of them have not applied large concepts (mega) in the variety of materials found, and also the types of materials used to make cultural objects. It can be seen from the objects used in ritual activities, the variety of materials for making containers in burial tradition, as well as profane buildings in the community both in the context of the past and in communities that still continue the tradition of ancestor worship.

The worshipping of ancestor worship in Indonesia indicated by the monuments built, was one of the characteristics of people life in Neolithic and Paleometalic era, which is able to extend through endless time. Even in several places in Indonesia, the evidences can be found up till now. In that cultural progress, various values and material shifting happened. Monumental shapes that were used as worshipping ancient/ancestor spirits instruments can be classified chronologically. Earlier, the objects that were considered as symbol of the death were menhir or long-shaped stones that are vertically built [17]. In the next development, the 
position of menhir was replaced by a simple stone statue, which was called a megalithic statue or a Polynesian type statue. Generally, wooden statues called by westerners as primitive art objects, are particular statue, which are connected with worship (cult object). The statue is that appearance could evoke empathy between the worshipper and the object of worship. The cult instruments in archeological found very different with another site in the world like at the Easter Island witch's build in a big size, in Indonesia it made in various size and dominantly not in a big size, not more than $1 \mathrm{~m}$ high.

In several places (areas) in Indonesia, those statues were not just made from stone material, but also made of wood. Traditions of using stones or wooden statues as ancestor magical elements context (ancestor poles) are still known at several local ethnic group (tribe) such as Sapundu (Dayak in Borneo), Mbis (Asmat in West Papua), and Ai Tos (Timor). One of the examples of progress can be seen on Manene Solemn (ceremony) at Tana Toraja (South Celebes) as worshipping instruments in ceremony wooden statue are built, which they called Tau-Tau. By the Tana Toraja community (especially on community with Auk Todolok belief) Tau-Tau is considered as statues as concrete forms of ancestor spirits. At given times those statues are dressed and given sacrifices.

Cult of ancestor spirits, as a matter of fact is still a belief among isolated tribal communities in Indonesia until now, i.e. the Dayak tribe (Borneo), the Tajio (Middle Celebes), the To Pembuni and To Seko (South Celebes), the Asmat (West Papua), the people of Nias (Sumatra), and so on. The belief in ancient spirits who occupying their surroundings, that had been appeared in the cult ceremonies of worshipping ancestor's spirits conducted by the Dayak community, in Kalimantan. They made wooden statues (hampatong and parekan), which were considered as concrete form of ancestor spirits. Statues are built in the front yard and on the balcony of the house (b'tang) [23]

Some tribes in Indonesia actually show the cult of ancestor worship that uses materials other than stones, like wood. This matter cannot be separated from the ancestral worship concept that already existed, though that monument was not made of a huge stone. With these data existence of the development of cultural worship value can be seen. The cult monuments for the ancestor spirits that are made of stones then are replaced by another material.

The changes in the material used to build the cult monument also adapt to the availability in the environment where the monument was built. At several locations in the western part of Java island, the stone terrace as a ritual site is built by stone blocks (columnar joint), slabs (sitting joint), boulders, or combination of slabs and boulders. Among others found on stone terrace of Gunung Padang site (Cianjur) which was used the stone blocks, Lebak Cibedug (Banten) by stone boulders, Arca Domas (Bogor) by stone slabs, and Hululingga (Kuningan) which constructed from the combination of slabs and boulders stone.

Like the cult or worshipping aspect, burial processes also show the shift of the use of material, although the making of burial case still comprises ancestor worship values. At several places though hard to determine claim the exact date burial cases generally were made from stones. Burial cases are named according to local terms like waruga, kalamba, pandusa, etc. Besides using stone as basic material for the making a case of burial, they also used wood. The use of wooden material as a burial case can be seen at later times, particularly in burial process at an advanced level or precisely at communities who are still having the ancestral beliefs concept, like the Toraja, and Dayak. In such community, burial case made of wood comprises two parts like a stone burial case, a case, and a cover.

So for the technical making wooden coffin was applied similar technique as the making of sarcophagus, waruga and so on. An example of a wooden coffin was the sandung, which was used by the Dayak community in Kalimantan. The technical making of the sandung is similar 
to the making of sarcophagus. Sandung was made from a huge chopped wood. On one part the hollowed part was made according to the size of the body. Then after the body was put in, the wood was covered like original wood [24]. The form of burial was called the primary burial system. At Dayak community, sandung also means as secondary burial, where the bones/skeleton of the dead in one family are put in together in one sandung, and then placed in the Balai Anting or above the front door of the house [25].

Here can be seen that after the era of using stones as burial case, later the stone is replaced by wood. However, a question arises whether the wooden burial case represents other form of megalithic burials like sarcophagus, and stone coffin, or the other way rounds. Because van Heekeren ever proposed that people who came to their places using boat might spread the sarcophagus and if they're any deaths, then they move to island. They made coffin from wood with resembled a boat. Then, those materials are replacing by stones [19].

Besides being used as material to build sacred monuments, wood was used to make profane objects which were represented the ancestor worship tradition. One of them is a ricepounding mortar, generally found in Kalimantan [23], [25]. That matter can be described as other form of stone mortars in other districts in Indonesia. Like the stone mortar, they use centrifugal process to make the wooden mortar. The wood is cutting down with subtractive method as a basin, on the top were made a hollow or more.

The emergence of mortar in human life, either made of stone or wood, actually could not separate from the ability of human to produce raw material that they need in daily life, like pounding rice or produce other materials such as medicine. It can be concluded here that wooden mortar was other form of stone mortar. This form in later tradition might happen because material was limited or practical reasoning.

\section{Conclusion}

From this explanation it is clear in cultural tradition of ancestor worship, the elements used to build monuments were not only made from the large stones but were also made with small sizes and other materials such as wood. Based on archeological remains and various forms of media used in ancestral breeding traditions in the past it can be concluded that the term megalithic that has been used is no longer in accordance with its etymology. Materials in cultural continuity found in archeological research and trade are not only made of stone, but also of wood. All of that is related to its function in ritual practice in the past.

\section{References}

[1] C. B. Casen, Serge, Pierre Petrequin, "Measurring Distinction in The Megalithic Architecture of The Carnac Region: From Sign to Material," www.juncsteinSITE.de, 2011.

[2] K. Goran Sjogren, "Megaliths, Lanscapes and Identities: the case of Fabygden, Sweden," www.juncsteinSITE.de, 2010 .

[3] and K. Y. J. Shekhar, Himanshu, Kantikumar Pawar, "Living Megalithicc Tradition Among the Munda Community of Jharkhandtle," J. Multidiciplinary Stud. Archaeol., vol. Vol 2.2014, 2014.

[4] S. Mendaly, "Funeral Rituals and Megalithic Tradition: A Study on Some Ethnic Community in South-Western Part of Odisha," J. Multidiciplinary Stud. Archaeol., vol. Vol.5, pp. 930-943, 2017.

[5] M. Pradipta, Martin, Dr. Rahadian Prajudi Herwindo, ST, "The Caracteristic Features of Megalithic Culture in Architecture of Temples on Island of Java (From The Ancient to Middle 
and Clasical Eras," Risa (Riset Arsit., vol. Volume 01, 2017.

[6] V. and C. R. Cummings, "The Essence of the Dolmen: The Architecture of Megalithic Construction," Open Ed. J., vol. 2019, 2019.

[7] D. Ayatrohaedi., Kamus Istilah Arkeologi. Jakarta: Proyek Penelitian Bahasa dan Sastra Indonesia dan Daerah, Depdikbud, 1978.

[8] N. N. Kradin, “Archaeological Criteria of Civilization,” Soc. Evol. Hist., vol. Vol.5 No., 2006.

[9] H. E. Loofs, Element of the megalithic complex in South East Asia. Canberra: Australian University Press., 1976.

[10] V. H. Geldern, "Prehistoric research in the Netherland indies," in Science and scientists in The Netherland indies., 1945.

[11] R. Blust, "The Austronesian Homeland: a linguistic perspective," Asian Perspect., vol. 26.1, pp. 45-68.

[12] P. Belwood, No Title. Jakarta: Gramedia Pustaka Utama, 2000.

[13] D. A. Tanudirjo, "Islands in Between, Prehistory of the Northeastern Indonesian Archipelago," Canberra: The Australian National University., 2001.

[14] A. A. Munandar, "Mengurai Kembali Peradaban Manusia (Rethinking Human Civilization)"," Depok, 2012.

[15] J. Thomas, Time, culture, and identity an interpretive archaeology. London and New York: Routledge., 1996.

[16] I. M. Sutaba, "Dinamika Dan Kepribadian Bangsa Yang Tercermin dari Tradisi Megalitik di Indonesia.," J. Arkeol. Indones. No. 2. Jakarta Ikat. Ahli Arkeol. Indones., vol. No.2, 1996.

[17] B. Prasetyo, "Budaya Megalitik di Indonesia," Solo, 2012.

[18] L. Yondri, Situs Gunung Padang, Kebudayaan, Manusia, dan Lingkungan, Edisi pert. Bandung: CV. Semiotika, 2016.

[19] Soejono, Jaman Prasejarah di Indonesia. Sejarah Nasional Indonesia I. Jakarta: PN. Balai Pustaka. 1984.

[20] V. der Hoop, Megalithic Remains in South Sumatra. Zutphen, 1932.

[21] F. A. Wagner, "Indonesia: The art of an island group.," in Art of the World Series., 1962.

[22] O. Sumarwoto, Ekologi, Lingkungan Hidup dan Pembangunan. Jakarta: Pernerbit Djambatan, 1994.

[23] \& V. T. K. Ave, Jan B., Borneo, people of weeping forest: Tradition and change in Borneo. Leiden, Netherlands: National Museum of Ethnology, 1986.

[24] A. . Kartawinata, "Masyarakat Punan di Kalimantan Barat," in Masyarakat Terasing di Indonesia, Jakarta: PT. Gramedia Pustaka Utama, 1993.

[25] R. Subagya, Agama Asli Indonesia. Jakarta: Sinar Harapan dan Yayasan Cipta Loka Caraka, 1981.

[26] K. Saddhono, "Integrating Culture in Indonesian Language Learning for Foreign Speakers at Indonesian Universities." J. of Lang. and Lit. vol. 6 no.2 pp. 349-353, 2015 